\title{
Timucua Hand Use: Dispelling the Claim of Left-Hand Preference
}

\author{
George Aaron Broadwell ${ }^{1}$ \\ ${ }^{1}$ University of Florida
}

\begin{abstract}
The Timucua were the original people of northern central Florida. Granberry (1996) claimed in a provocative article that Timucua constitutes an exception to the universal or near-universal property of preference for the right hand, and showed a preference for the left hand instead. This article critically examines Granberry's argument, and shows that there is no good linguistic evidence to support left-hand preference in Timucua.
\end{abstract}

Keywords: Left; Right; Timucua Language; Hand-Preference; Catholicism.

\section{Human Universals and Grandberry's Claim}

Among the strongest candidates for a human cultural universal is the claim that societies tend to favor the right hand over the left. Brown (2004) has stated the universal as a conditional, in the following way: "If a society shows a preference for one hand over the other, as many Western societies do, then it is always the right hand." From a linguistic point of view, there is good evidence for a similar universal, which we could state as "If a language associates 'right' and 'left' with positive and negative attributes (such as 'good/bad', 'strong/weak', 'agile/clumsy'), then the language associates 'right' with positive attributes."1

Thus, it is surprising, and relevant to Florida anthropologists, to find the claim that the Timucua, the indigenous people of much of North Florida and adjacent parts of Georgia, showed a different pattern. Granberry (1996:188) has written. ${ }^{1}$

...the now extinct Timucua language of North Florida and South Georgia used the word eba 'strong, healthy, lucky, fortunate' for 'left hand' and the word fara 'dislike, ruin (noun or verb), weak, sickly, scandal, misfortune' for 'right hand', a mirror image of standard Indo- European usage (see Granberry 1990; 1991; 1993). The primary meaning of Timucua eba is 'paddle, oar', and its semantic extension to 'strong' in a society oriented toward water and riverine travel, where a good rowing arm was all-important, does not require a great stretch of the imagination. Its extension to mean 'left hand', however, is indeed unusual. That semantic peculiarity is accompanied by extension of the meaning of fara 'dislike, weak, misfortune' to 'right hand'...

The purpose of this brief article is to refute Granberry's claim that in the Timucua language the word for 'left hand', eba is associated with the meanings 'strong, healthy, lucky, fortunate', while the corresponding word for 'right hand' is associated with meanings like 'dislike, ruin (noun or verb), weak, sickly, scandal, misfortune'.

\footnotetext{
${ }^{1}$ See Schiefenhövel (2017) and Foolen (2019) for surveys of many languages which show such associa-
} tions. 


\section{The Timucua People and Their Language}

The Timucua were the original people of northern central Florida, and lived in an area from the Atlantic coast to the Gulf of Mexico. At the time of Spanish contact, their territory spread as far north as southeast Georgia and south to around Ocala, FL. ${ }^{2}$ Timucuaspeaking people were first contacted by Europeans in 1513, but intensive contact came in 1565 with the establishment of the Spanish colony at St. Augustine, FL. In 1595, the Franciscans established missions to convert the Timucua to Christianity. With the assistance of Timucua converts, the Franciscans produced a large number of Timucua language documents.

The primary person responsible for introducing literacy to the Timucua was Friar Francisco Pareja. Pareja's work was continued by Gregorio de Movilla, another Spanish friar, who oversaw the production of other religious documents in Timucua. Although the religious documents have only the names of the Franciscan friars attached to them-effectively giving the friars the sole credit for their production-a closer look reveals that the Timucua portions of documents are more likely to have been written by Timucua writers themselves, under the direction of Pareja and Movilla (Dubcovsky and Broadwell 2017).

In the course of two centuries after Spanish contact, the Timucua faced warfare and epidemic disease, until the recorded number of Timucua people associated with these missions was reduced from an estimated 200,000 persons at the time of contact to less than a hundred in the mid-18th century. In 1763, as the Spanish ceded La Florida to the English, Timucua people at the missions, some of them converts, and other Indigenous refugees, left Florida for Cuba. Their language, Timucua, has not been spoken since around the middle of the 18th century.

Our knowledge of Timucua comes almost entirely from 17th century Spanish colonial documents, which are described in section 3 below. The name of the language is usually spelled Timuqua or Timuquana in the documents described in the corpus below.

There are explorations of a few areas of Timucua grammar in Gatschet $(1877,1878$, 1880), de la Grasserie (1893) and in Adam and Vinson (1886). The only modern account of Timucua grammar is Granberry (1993), but there are large gaps in his account of the language. In recent years, I and my coauthors have published a number of additional works on the Timucua language which challenge Granberry's reconstruction of the grammar. These include Broadwell (2015), Dubcovsky and Broadwell (2017), Broadwell (2018), Broadwell (2019a), and Broadwell and Dubcovsky (to appear). ${ }^{3}$

Timucua is probably related to Tawasa, a language of which we have only fragmentary records (Swanton 1929). Apart from Tawasa, Timucua does not have any generally

2 The Timucua were composed of several rival political units (the largest of which were known as Mocama, Utina, Timucua, and Potano) who appear to have shared a single language. The Spanish referred to their language collectively as Timucua, taking the name of one of these political units as the name for the whole language. Milanich (1996).

${ }^{3}$ I thank Lisa Noetzel, Danny Hieber, Jack Martin, Alejandra Dubcovsky, Ives Goddard, as well as students in my 2018 Timucua class (Helaire Echo-Hawk, Alli Fuijmoto, Estefania Baranger, Andrea Arseneau, Noella Handley, Mosiah Bluecloud, Clinton Parker, Nelson Santiago, and Abraham Nygren) for helpful suggestions and comments on the analysis of Timucua grammar. I thank Michael Stoop, Christopher Muntzner, Alex Webber, Anna Bjorklund, Chait Singh, Sara Carruthers, Martin Melgar, Seth Katenkamp, Ana Rodriguez, Karen Burgos, Natasha Kelly, Joshua Killingsworth, Jennifer Sierra, and Michael Springthorpe for their contributions to the Timucua database project. This grammar was written using XLingPaper, a software package for writing linguistic documents. I thank Andy Black for his assistance in designing XLingPaper and guidance with multiple formatting issues.

Broadwell, G.A. (2021) Timucua Hand Use: Dispelling the Claim of Left-Hand Preference. New Florida Journal of Anthropology 1(2), 18-29 DOI: 10.32473/nfja.v1i2.123622 
accepted relationships with other language families of the world. Crawford (1988), Swanton (n.d), and Broadwell (2015) have suggested possible connections with Muskogean languages.

\section{The Timucua Language Corpus and Principles for Building a Dictionary}

In order to get a better understanding of the Timucua lexicon and the grammar of the language, I have worked with students to develop a corpus of the extant Timucua texts, along with their parallel Spanish translations. New material is still being added to the corpus, with an eventual aim of including all Timucua text. The current corpus is about 137,000 orthographic words of Timucua, and is composed of the material listed in Appendix A. ${ }^{4}$

The corpus has been analyzed with Fieldworks Language Explorer (FLEx), a lexicography and text analysis tool designed by SIL. ${ }^{5}$ Because Timucua has no complete dictionary, the meanings of most words and morphemes in the texts have to be deduced by examining multiple contexts of use. The powerful concordance functions of FLEx and its abilities to ensure consistency in interlinear glossing were extremely helpful in deciding on likely glosses for the material.

There is no known dictionary of Timucua from the Spanish colonial period, thus any attempt to write a dictionary of the language is a matter of carefully examining the colonial documents for the evidence for particular words and the meanings associated with them. The clearest evidence often comes from Pareja (1614), since about 400-500 distinct lexical roots are listed there along with their Spanish translations. ${ }^{6}$

Dictionaries can vary enormously in quality, but dictionaries of language that are no longer spoken and which are based only on written material face a number of additional problems. Since we cannot consult with speakers of Timucua, asserting that a particular form in Timucua has a particular meaning is a matter of assembling evidence from the texts to show this.

Unfortunately, the primary published dictionary of Timucua (Granberry 1993), does a very poor job of demonstrating any evidence for the entries posited. Broadwell (2019b) is an attempt to produce an improved Timucua dictionary which cites explicit evidence for each entry, and which also ranks the confidence with which we can assert particular meanings.

Entries are ranked as Confident if they are explicitly translated in Pareja (1614) or if there are several clear examples in the texts which allow us to posit a meaning with a high level of confidence. Probable means that there is good evidence for this meaning, but it is not beyond doubt.

\footnotetext{
${ }^{4}$ I refer here to orthographic words, that is, sequences of letters separated by spaces from othersequences. It is difficult to give a reliable figure for the number of morphological words in the corpus, because the idea of orthographic word and morphological word are fairly discrepant in Timucua. The colonial authors were inconsistent in their writing of Timucua. Thus what appears to be a single Timucua morphological word like naquosonolebima might be written in different places as <na quosono leui ma >, <naquoso no leui ma>, $<$ naquosono le uima >, <naquosonoleui ma>, etc. It is also often difficult to determine the spacing between orthographic words in the printed Timucua materials, since the texts are all justified with flush right margins, and thus the spacing between the letters varies in order to fit the line.

${ }^{5} \mathrm{SIL}$ (formerly Summer Institute of Linguistics) is a Christian non-profit organization which produces a range of software for language documentation and literacy. https://software.sil.org/fieldworks/

${ }^{6}$ Timucua is a language with very long words, generally composed of a root plus many prefixes and suffixes. The estimate of 400-500 is based on the number of distinct roots, not the number of distinct words. Broadwell, G.A. (2021) Timucua Hand Use: Dispelling the Claim of Left-Hand Preference. New Florida Journal of Anthropology 1(2), 18-29 DOI: 10.32473/nfja.v1i2.123622
} 


\section{The Words for 'Right' and 'Left' in Timucua}

Though Granberry (1996) asserts that the Timucua words for 'right' and 'left' are fara and eba respectively, the article actually provides no linguistic evidence for this assertion, but instead focuses on artistic depictions of Timucua people and attempts to determine which hand is being used. For the meanings of these words, he refers the reader to the dictionary contained in Granberry (1993). As discussed in section 3, Granberry's dictionary provides no evidence for most of the words given there.

So what is the data? The clearest evidence for 'left' and 'right' is found in a list of adverbs at Pareja (1614:f139r), which says

'A man[o] derecha ó acia ó a la mano diestra' [The right hand, or toward or to the right hand] farane betá. Acia la izquierda ó siniestra [toward the left] eba beta.

Thus evidence from Pareja (1614) shows that Granberry is correct about the word eba 'left', but the form listed for 'right' is not fara, as he claims, but farane. The word beta in Pareja's passage is a postposition that corresponds to several English prepositions, including 'to, toward, from, at'. In examples below, it is labeled 'obl(ique)', a grammatical label that covers this wide range of spatial senses. ${ }^{7}$

A further search through the corpus of Timucua textual material reveals clear evidence that eba does mean 'left', but the word for 'right' should actually be farano. The final letter $<\mathrm{e}>$ in Pareja (1614) is thus probably a print or transcription error for $\langle 0\rangle$, for there are no other textual instances of farane.

Consider the following passage (1) describing how to make the sign of the cross: ${ }^{8}$

(1)

$\begin{array}{lllll}\text { huqui ebabeta } & \text { qeleta, } & \text { huqui } & \text { faranobeta } & \text { naminosomano... } \\ \text { huqui eba beta qele-ta } & \text { huqui } & \text { farano beta } & \text { na-mino-so mano... } \\ \text { shoulder left OBL make:line-PART } & \text { shoulder } & \text { right OBL } & \text { INS-come-CAUS-TOP } \\ \text { del ombro izquierdo al derecho } & & \\ \text { from the left shoulder to the right } & \end{array}$

Though the word for 'left' is not very common in the corpus, there are many more instances of farano 'right', often in the phrase 'at the right hand of God the father', which forms part of the Apostles' Creed.

\footnotetext{
${ }^{7}$ In the Timucua language words spelled with $<b>$ often show alternate spellings with $<$ bu $>$. Thus, the two words discussed in this paragraph, eba and beta also have alternate spellings ebua and bueta, seen in some examples such as (2). See Dubcovsky and Broadwell (2017) for a longer discussion of dialect differences in these spellings.

8 Timucua examples use the following abbreviations: $1=$ first person, $3=$ third person, def $=$ definite, ben = benefactive, caus $=$ causative, aff $=$ affirmative, dur $=$ durative, , hon $=$ hon- orific , indef $=$ indefinite, ins $=$ instrumental, $\mathrm{nmlz}=$ nominalizer/nominalization, nom $=$ nom- inative, obl $=$ oblique, part $=$ participle, $\mathrm{pl}=$ plural, poss $=$ possessive, pres $=$ present, prev $=$ previously mentioned, subj $=$ subject, top $=$ topic.

Broadwell, G.A. (2021) Timucua Hand Use: Dispelling the Claim of Left-Hand Preference. New Florida Journal of Anthropology 1(2), 18-29 DOI: 10.32473/nfja.v1i2.123622
} 
(2)

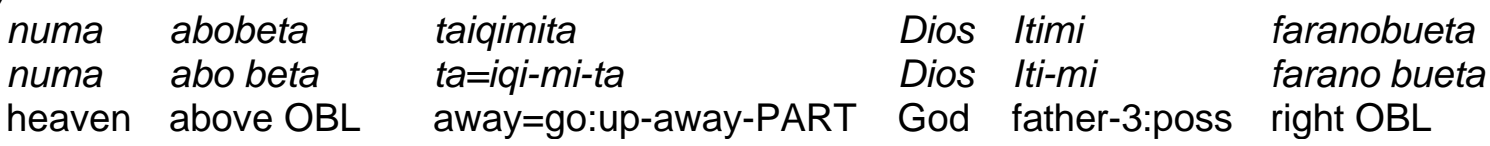

nahibuata

na-hibua-ta

INS-sit-PART

subio a los Cielos, donde esta assentado a la diestra de Dios Padre

rose to heaven, where he is seated at the right of God the Father

Lit. he rose up to heaven above and sits at the right hand of God the Father

Pareja (1612b:f27)

In the following passage, farano beta 'at the right hand' appears in a description of the place of Adam's chair in heaven:

(3)

$\begin{array}{llll}\text { Dios vtina } & \text { faranobeta } & \text { aye hibuano, } & \text { ychunte } \\ \text { Dios vtina } & \text { farano beta } & \text { aye hibuano, } & \text { ychu-nte } \\ \text { God Utina } & \text { right OBL } & \text { chair } & \text { be:placed-DUR }\end{array}$

sentandose à la diestra del Padre

seated at the right hand of the Father

Lit. the chair is placed at the right hand of God Utina

Pareja (1627a:f83r)

And finally, the following passage describes the creation of Eve from Adam's right rib: 9

(4)

$\begin{array}{llllll}\text { Adam, chocolo } & \text { faranobeta } & \text { yabi } & \text { piriqui } & \text { yaha } & \text { iposta } \\ \text { Adam, chocolo } & \text { farano beta } & \text { yabi } & \text { piriqui } & \text { yaha } & \text { iposta } \\ \text { Adam side } & \text { right OBL } & \text { bone } & \text { rib? } & \text { one } & \text { remove-BEN-PART }\end{array}$
sacale Dios vna costilla

God takes a rib from him

Lit. Lit. he removed one rib from Adam's right side

Pareja (1627a:f39v)

Having established that 'right' is farano and 'left' is eba, what are the larger semantic associations of these words? I will examine possible connections between left and right in the following sections.

\section{The left hand and the oar}

\section{Timucua Associations of 'Left'}

Granberry (1996) claims that the primary meaning of Timucua eba is 'paddle, oar', but this assertion is not well-grounded. The word 'oar' (Spanish remo) is scarce in the

\footnotetext{
9 Yabi means 'bone' and the compound yabi piriqui appears to mean 'rib'. However, the word piriqui does not appear anywhere else in the corpus and thus we cannot be certain of it.

Broadwell, G.A. (2021) Timucua Hand Use: Dispelling the Claim of Left-Hand Preference. New Florida Journal of Anthropology 1(2), 18-29 DOI: 10.32473/nfja.v1i2.123622
} 
corpus, but does appear twice in the Arte, in the following examples: ${ }^{10}$

(5)

a.

$\begin{array}{lll}\text { nacorinòma } & \text { l. } & \text { ebuasoma } \\ \text { nacorino-ma } & \text { l. } & \text { ebuaso-ma } \\ \text { oar-DEF } & \text { or } & \text { oar-DEF }\end{array}$

el remo con que se boga o rema.

the oar with which one rows or paddles

b.

$\begin{array}{ll}\text { ebuasoma } & \text { aba-la } \\ \text { ebuaso-ma } & \text { aba-la } \\ \text { oar-DEF } & \text { injure:self-AFF } \\ \text { Con el remo se dió } & \\ \text { He hit himself with the oar. }\end{array}$

Pareja (1614:f50)

Pareja $(1614: f 50)$

From these, we can see that the word for 'oar' is ebuaso. There is no clear connection between eba 'left' and ebuaso 'oar'. The first two syllables are almost identical, but the additional/so/ syllable has no explanation, and thus I see no good evidence for a relationship.

\section{The left hand and good fortune}

Granberry (1996) claims that eba also means 'strong, healthy, lucky, fortunate'. However, this is not the case. The current Timucua lexicon has the following words which begin with the syllables /eba/:

- ebacaleale, V, 'to bury', Pareja (1614:f46), [Confidence level: Confident]

- ebacani, V, 'to want, prefer' [Confidence level: Probable]

- ebahio, V, 'be merciful' [Confidence level: Confident]

- ebami, N, 'wound' [Confidence level: Probable]

- ebamichiqe, Adj, 'wounded' [Confidence level: Confident]

As inspection of the list shows, none of the meanings that Granberry associates with eba are currently supported by the data.

\section{Timucua Associations of 'Right'}

Granberry (1996) claims that fara means "dislike, ruin (noun or verb), weak, sickly, scandal, misfortune'. In this case, Granberry is less obviously incorrect. The current Timucua lexicon has the following two words which begin with the syllables /fara/:

- fara fara, Adj, 'broken' [Confidence level: Probable]

- faramiti, Adj, 'despicable, miserable' [Confidence level: Confident]

These do look as if they have negative associations. However, recall that the

\footnotetext{
10 The I. which appears between the two forms given in (5a) is an abbreviation of Latin vel 'or', and is used by Pareja when giving alternate translations.

Broadwell, G.A. (2021) Timucua Hand Use: Dispelling the Claim of Left-Hand Preference. New Florida Journal of Anthropology 1(2), 18-29 DOI: 10.32473/nfja.v1i2.123622
} 
Timucua word for 'right' is farano, not fara.

From an etymological point of view, however, it is not legitimate to suggest that two words have a common root just because they share a syllable or syllables. The English word fur is not related to furniture, nor is there any semantic connection between chair and charity. To maintain the connection, a linguist would need to be able to explain how the different parts of the word farano are composed.

Timucua does have a suffix -no which appears on the ends of verbs to form nominalizations. Nominalizations with -no most frequently refer to events, the results of events, or abstract notions as in the following examples (6). ${ }^{11}$

\begin{tabular}{|c|c|}
\hline a. & $\begin{array}{l}\text { ituhu-nu } \\
\text { pray-NMLZ } \\
\text { prayer }\end{array}$ \\
\hline b. & $\begin{array}{l}\text { balu-nu } \\
\text { live-NMLZ } \\
\text { life }\end{array}$ \\
\hline c. & $\begin{array}{l}\text { yayi-no } \\
\text { be strong-NMLZ } \\
\text { strength }\end{array}$ \\
\hline d. & $\begin{array}{l}\text { hebua-no } \\
\text { speak-NMLZ } \\
\text { speech, word }\end{array}$ \\
\hline e. & $\begin{array}{l}\text { chebe-no } \\
\text { lose-NMLZ } \\
\text { loss }\end{array}$ \\
\hline f. & $\begin{array}{l}\text { hiquotimo-no } \\
\text { marvel-NMLZ } \\
\text { miracle }\end{array}$ \\
\hline
\end{tabular}

As (6c) shows, some of the words which appear with the -no suffix are adjectivelike. Since fara is an adjective meaning 'broken', then we would expect its nominalization with -no to be a noun meaning something like 'brokenness'. It is not impossible that there is some connection between 'brokenness' and 'right', as Granberry suggests. But such a connection is not obvious, and we would need to weigh that possibility against the possibility that farano 'right' is only accidentally similar in sound to other words that start with /fara/.

\footnotetext{
11 Timucua has a process known as 'vowel harmony' which causes - no to appear as - nu when the final vowel of the preceding verb stem ends with $/ \mathrm{u} /$.

Broadwell, G.A. (2021) Timucua Hand Use: Dispelling the Claim of Left-Hand Preference. New Florida Journal of Anthropology 1(2), 18-29 DOI: 10.32473/nfja.v1i2.123622
} 


\section{Catholic Associations of 'Right' and 'Left'}

Finally, I would like to raise an additional objection to Granberry's claim. This comes from the nature of the texts translated into Timucua. These are nearly all Catholic texts, and they display the common European bias for the right hand over the left. (2) above):

A very common phrase showing the preference for the right is (7), (repeated from

(7)

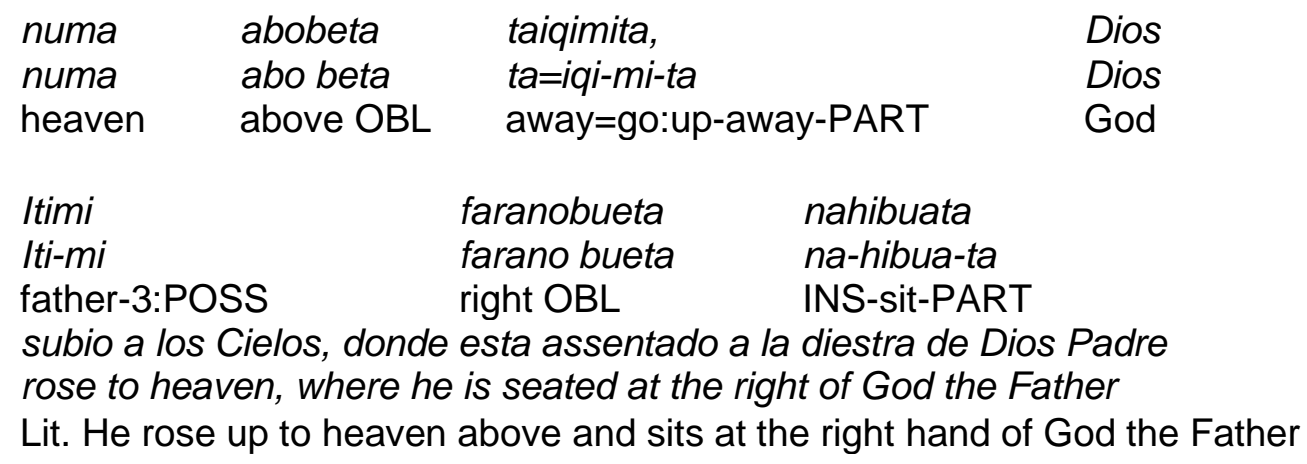

Pareja (1612b:f27)

In Christian theology, Jesus sits on the right hand of God because the right side is the better and more preferable side.

Other passages like (8) also talk preferentially about the right side. In this case, one sings at the right side of the altar because it is the better side.

(8)

$\begin{array}{lllll}\text { Euangelio, altarbasala } & \text { faranobeta } & \text { elono } & \text { letemichunu, } \\ \text { Evangelio } & \text { altar basala } & \text { farano beta } & \text { elo-no } & \text {-lete-michu-nu, } \\ \text { Gospel } & \text { altar at:distance } & \text { right OBL } & \text { sing-NMLZ } & \text {-INDEF:SUBJ-PREV-TOP }\end{array}$

$\begin{array}{lllll}\text { lesu, Christo } & \text { anocomile } & \text { iribota } & \text { hebano } & \text { mitonoma, } \\ \text { lesu Christo } & \text { anoco-mile } & \text { iribo-ta } & \text { hebano } & \text {-mitono-ma, } \\ \text { Jesus Christ } & \text { lord-1:PL:POSS } & \text { stand-PART } & \text { word } & -3: H O N: P O S S-D E F \\ \text { nibitela. } & & & \\ \text { nibi-te-la } & \\ \text { resemble-PRES-AFF. } \\ \text { Lit. The Gospel is like the preaching of Jesus Christ our Lord, when one sings at the right } \\ \text { hand of the altar. }\end{array}$

Movilla (1635:f74v)

If the Timucua people, as Granberry asserts, associated the right side with ruin and misfortune, would we not expect passages in Catholic religious that associate the right side with good fortune to create a conflict?

Other parts of Timucua Christian literature give additional clarifications or justifications when there is a discrepancy between the Timucua and the Catholic understanding of certain words. For example, Pareja (1612b) contains long discussions of the differences in meaning between Spanish words like hijo 'son' and their Timucua equivalents. 
A profound difference in evaluation between the value of the right and the left sides of the body should have been quite obvious to the Franciscan missionaries and to Timucua converts to Christianity. Yet nothing in Timucua literature or in the correspondence of the Franciscans alludes to such a difference.

\section{Conclusion}

The claims of Granberry (1996) are not supported by any linguistic or textual data currently in evidence. There is no good reason to believe that the Timucua people favored the left hand over the right. Granberry's arguments in favor of this position are largely based on unproven etymologies of Timucua language data.

Thus the human universal suggested by Brown (2004) is not contradicted by any good evidence from Timucua.

\section{Appendix A: The Timucua Corpus}

The Timucua corpus is still in development and new material is being added. The current version contains the following material.

1. Pareja (1612a), a catechism in parallel Timucua and Spanish. This is also called the "Short Catechism" in comparison with the longer 1627 Catechism Pareja (1627a)

2. Pareja (1612b), a catechism. This is called the First Catechism in Gatschet $(1877,1878,1880)$, where some passages of this manuscript are transcribed. ${ }^{12}$ This book has no page numbers, but references to locations are via the page number assigned in the electronic copy at http://dcmny.org/islandora/object/nyhs\%3A2261\#page/1/mode/2up.

3. Pareja (1613), a confessional in parallel Timucua and Spanish.

4. Pareja (1614), a Latinate grammar of the language, usually referred to as the Arte. A version of the Arte has been been published as Adam and Vinson (1886). I also consulted Martin and Reed (in preparation), a revised transcription of the Arte.

5. Pareja (1627a), a Catechism. This text deals with the creation of the world, the birth of Jesus Christ, and his death and resurrection. The majority of the Timucua portions in this book do not correspond directly to the Spanish text, which is generally only a summary of the Timucua.

6. Pareja (1627b), a second Catechism. This text focuses on the nature of the sacrament.

7. Pareja (1628). This text focuses on the nature of the mass, and its title, 'IIII Parte del Catecismo', shows that Pareja probably conceived of the two parts of Pareja (1627a), Pareja (1627b), and Pareja (1628) as a large connected work.

8. Movilla (1635), a doctrina (explanation of Catholic doctrine). This is an almost entirely monolingual Timucua book. However, as its Spanish title page explains, it is a translation of Belarmino (1614), a widely circulated doctrinal source.

\footnotetext{
12 Sometimes this version is also referred to as the "Baptism" text, since it contains the baptismal ceremony and refers to baptism in its title.

Broadwell, G.A. (2021) Timucua Hand Use: Dispelling the Claim of Left-Hand Preference. New Florida Journal of Anthropology 1(2), 18-29 DOI: 10.32473/nfja.v1i2.123622
} 
9. An unpublished 1651 letter from Timucua leaders to the Spanish crown Manuel (1651), generally referred to as the Jesus Maria letter. A copy is in the National Anthropological Archives (NAA Cat 2446-f) and a translation is forthcoming as Broadwell and Dubcovsky (to appear).

10. A few examples from a second 1688 letter, which is published as Smith (1860).

\section{References}

Adam, Lucien and Julien Vinson, eds. (1886) Arte de la lengua timuquana, compuesto en 1614 por el padre Francisco Pareja, y publicado conforme al ejemplar original único. Paris: Maisonneuve Frères et Ch. Leclerc.

Belarmino, Roberto (1614) Declaracion de la doctrina Christiana: Por orden del Sanctissimo Padre Clemento Octavo, de felice recordacion. Por el illustriss[imo] y Reverendiss[imo] señor Cardenal Roberto Belarmino, de la Compania de lesus. Aprovado por la Congregacion de la reforma, para el uso delos que enseñan, y aprenden la Doctrina Christiana. Traduzida de Latin en Castellano por Luyz de Vera secretario del Duque de Monteleon. Lisbon: Antonio Alvarez.

Broadwell, George Aaron (2015) Timucua -ta: Muskogean parallels. In Michael D Picone and Catherine Evans Davies, eds. New perspectives on language variety in the South: Historical and contemporary approaches, 72-81. Tuscaloosa, AL: University of Alabama.

Broadwell, George Aaron (2018) Shadow authors: The texts of the earliest indigenous Florida writers. In Jeffrey Burns and Timothy Johnson, eds. Franciscans and American Indians in Pan-Borderlands Perspective, 139-152. Oceanside, CA: Academy of American Franciscan History.

Broadwell, George Aaron. (2019a). Honorific usage in Timucua exempla. In Timothy Johnson, Katherine Wrisbey Shelby, and John D. Young, eds. Preaching and New Worlds, 280294. New York: Routledge.

Broadwell, George Aaron (2019b).A Timucua-English Dictionary. https:/timucua.webonary.org/ (Dec 12, 2019).

Broadwell, George Aaron and Alejandra Dubcovsky. (to appear). I will not divide or give it: Translation of a 1651 Timucua letter. Transactions of the American Philosophical Society.

Brown, Donald E. (2004) Human universals, human nature, and human culture. Daedalus 133(4):47-54.

Crawford, James M. (1988) On the relationship of Timucua to Muskogean. In William Shipley, eds. In honor of Mary Haas, 157-164. Berlin: Mouton de Gruyter.

Dubcovsky, Alejandra and George Aaron (2017) Writing Timucua: Recovering and Interrogating Indigenous Authorship. Early American Studies: An Interdisciplinary Journal 15:409-441.

de la Grasserie, Raoul (1893) Esquisse d'une grammaire du Timucua. Orleans: G Jacob. 
Foolen, Ad (2019) The value of left and right. In J. Lachlan Mackenzie and Laura Alba-Juez, eds. Emotion in discourse, 139-158. Amsterdam: John Benjamins.

Gatschet, Albert (1877) The Timucua language. Proceedings of the American Philosophical Society 16:1-17.

Gatschet, Albert (1878) The Timucua language. Proceedings of the American Philosophical Society 17:490-504.

Gatschet, Albert (1880) The Timucua language. Proceedings of the American Philosophical Society 18:465-502.

Granberry, Julian (1990) A grammatical sketch of Timucua. International Journal of American Linguistics 56:60-101.

Granberry, Julian (1991) Amazonian affiliation of the Timucua Language. In Mary Ritchie Key, eds. Language Change in South American Languages. 195-242. Philadelphia: University of Pennsylvania.

Granberry, Julian (1993) A Grammar and Dictionary of the Timucua Language. Tuscaloosa, AL: University of Alabama Press.

Granberry, Julian (1996) Eba/fara: An ethnolinguistic note on Timucua hand use. International Journal of American Linguistics 62(2):188-195.

Manuel, Cacique (1651) Jesus María Letter, December 9, 1651, translated into Spanish by Fray Alonso Cuaderas. Ms. 2446-f, reel 6. National Anthropological Archives, Smithsonian Institution. ms.

Martin, Jack and Ann Reed. (in preparation.) "edition of Pareja 1614." College of William and Mary. ms.

Milanich, Jerald. 1996. The Timucua. Oxford: Blackwell.

Movilla, Gregorio de (1635) Explicacion de la Doctrina que compuso el cardenal Belarmino, por mandado del Señor Papa Clemente 8. Traducida en Lengua Floridana: por el Padre Fr. Gregorio de Movilla. Mexico: Imprenta de luan Ruyz.

Pareja, Francisco (1612a) Catechismo y breve exposición de la doctrina christiana. Mexico City: Casa de la viuda de Pedro Balli.

Pareja, Francisco (1612b) Cathecismo en lengua castellana, y Timuquana. En el qual se contiene lo que se les puede enseñar a los adultos que an de ser baptizados. Mexico City: Impresa de la Viuda de Pedro Balli.

Pareja, Francisco (1613) Confessionario en lengua castellana y timuquana con unos consejos para animar al penitente. Mexico City: Emprenta de la viuda de Diego Lopez Daualos.

Pareja, Francisco (1614) Arte y Pronunciacion de la Lengua Timucvana y Castellana. Mexico City: Emprenta de loan Ruyz. 
Pareja, Francisco (1627a) Catecismo en lengua timuquana y castellana en el qual se instruyen y cathequizan los adultos infieles que an de ser Christianos. Mexico City: Emprenta de loan Ruyz.

Pareja, Francisco.(1627b) Cathecismo y Examen para los que comulgan. En lengua castellana y timuquana. Mexico City: Imprenta de luan Ruyz.

Pareja, Francisco (1628) IIII Parte del Catecismo, en lengua timuquana y castellana. Mexico City: Imprenta de luan Ruyz.

Schiefenhövel, Wulf (2017) Biased semantics for right and left in 50 Indo-European and non-IndoEuropean languages. Annals of the New York Academy of Sciences 1288:135-152.

Smith, Buckingham (1860) Dos cartas en lengua apalachino y timuguana. New York: Privately printed.

Swanton, John R. (n.d.) A Sketch of the Timucua Language. Bureau of American Ethnology, Smithsonian Institution ms 2446-g. ms.

Swanton, John R. (1929) The Tawasa language. American Anthropologist 31:435-45 